\title{
Desulfovibrio longus sp. nov., a Sulfate-Reducing Bacterium Isolated from an Oil-Producing Well
}

\author{
M. MAGOT, ${ }^{1 *}$ P. CAUMETTE, ${ }^{2}$ J. M. DESPERRIER,${ }^{3}$ R. MATHERON,${ }^{4}$ C. DAUGA,${ }^{3}$ \\ F. GRIMONT, ${ }^{3}$ AND L. CARREAU ${ }^{1}$ \\ Sanofi ELF Biorecherches, Unité de Microbiologie, Labège Innopole, BP 137, 31676 Labège Cedex, ${ }^{1}$ \\ Université de Bordeaux, Institut de Biologie Marine, Microbiologie, 33120 Arcachon, ${ }^{2}$ Institut \\ Pasteur, Unité des Entérobactéries, U199 INSERM, 75724 Paris Cedex 15, ${ }^{3}$ and Laboratoire \\ de Microbiologie, Faculté des Sciences St-Jérôme, 13397 Marseille Cedex 13, ${ }^{4}$ France
}

\begin{abstract}
A novel type of sulfate-reducing bacteria with unusual morphology was isolated from an oil-producing well in the Paris Basin. The cells of this bacterium, strain SEBR $2582^{T}(T=$ type strain), are long, thin, flexible rods, contain desulfoviridin, and are physiologically similar to members of the genus Desulfovibrio. On the basis of 16S rRNA sequence data, this strain should be included in the genus Desulfovibrio. However, strain SEBR $2582^{\mathrm{T}}$ differs from other members of this genus morphologically, physiologically, and phylogenetically. Thus, a new species, Desulfovibrio longus sp. nov., is proposed for this organism.
\end{abstract}

As an end product of anaerobic respiration, sulfate-reducing bacteria (SRB) produce hydrogen sulfide, a toxic compound which may accumulate in various anoxic sediments of ponds, lakes, coastal lagoons, or marine environments (14). SRB are also present in oil production facilities, where these bacteria cause severe economic losses due to iron corrosion in the absence of air, as well as to the in situ production of $\mathrm{H}_{2} \mathrm{~S}$ which results in the souring of oil reservoirs during secondary oil recovery $(2,6)$. Although a knowledge of the diversity of SRB in these industrial environments is necessary to improve treatments to prevent the detrimental effects of these organisms, little attention has been paid to identification of SRB, and few species of SRB isolated from oil field waters have been described (6). Recently, Rozanova et al. (21) isolated a new species of a new genus (Desulfomicrobium apsheronum) from an oil-bearing deposit. During the course of a microbiological study of several oil field waters, we isolated various unknown strictly anaerobic bacterial strains, including some SRB. The cells of one of these bacteria, strain SEBR $2582^{\mathrm{T}}$ ( $\mathrm{T}=$ type strain), are long, gracile rods that have an unusual morphology. Jones (13) first described this morphological type of SRB, and more recently, Widdel (23) isolated a similar bacterial type; however, these strains were never described as new species. Despite the morphology of strain SEBR $2582^{\mathrm{T}}$, the results of physiological and genetical analyses of this organism led us to assign it to the genus Desulfovibrio. However, strain SEBR $2582^{\mathrm{T}}$ is not a member of a previously described species of this genus. In this paper we describe this strain and identify it as a new species. The name Desulfovibrio longus sp. nov. is proposed.

\section{MATERIALS AND METHODS}

Source of the isolate. Strain SEBR $2582^{\mathrm{T}}$ was isolated from an oil-producing well in the Paris Basin (France). The production fluid (oil-water emulsion) was collected at the top of the well after extensive draining of the tubing. Sterile plasma bottles were used for sampling. Aliquots of the aqueous phase were anaerobically injected into SRB detec-

\footnotetext{
* Corresponding author
}

tion kits (type SEBR-A1), which have been described previously (15). The tubes were then incubated in the dark at $30^{\circ} \mathrm{C}$. After 3 days of incubation, a black precipitate of $\mathrm{FeS}$ in the tubes revealed the presence of sulfide; then the isolation of SRB was begun.

Isolation and maintenance in pure culture. SRB were isolated by using the streaking method on agar medium in petri dishes that were incubated in an anaerobic glove box with a gas mixture containing $\mathrm{N}_{2}, \mathrm{H}_{2}$, and $\mathrm{CO}_{2}$ (85:10:5). The culture medium used for isolation contained (per liter of distilled water) $2.0 \mathrm{~g}$ of $\mathrm{Na}_{2} \mathrm{SO}_{4}, 0.3 \mathrm{~g}$ of $\mathrm{KHCO}_{3}, 1.0 \mathrm{~g}$ of $\mathrm{CaCl}_{2} \cdot 2 \mathrm{H}_{2} \mathrm{O}, 1.0 \mathrm{~g}$ of $\mathrm{MgSO}_{4} \cdot 7 \mathrm{H}_{2} \mathrm{O}, 1 \mathrm{ml}$ of a $0.4 \%$ $\mathrm{FeSO}_{4} \cdot 7 \mathrm{H}_{2} \mathrm{O}$ solution, $3.0 \mathrm{~g}$ of MOPS (morpholinepropanesulfonic acid) buffer, $1.0 \mathrm{~g}$ of $\mathrm{NH}_{4} \mathrm{Cl}, 6.0 \mathrm{ml}$ of a $60 \%$ sodium lactate solution, $1.0 \mathrm{~g}$ of sodium acetate, $1.0 \mathrm{~g}$ of yeast extract, $0.5 \mathrm{~g}$ of cysteine hydrochloride, and $16 \mathrm{~g}$ of agar. The $\mathrm{pH}$ was 7.4 , and the medium was anaerobically distributed into bottles and autoclaved for $30 \mathrm{~min}$ at $105^{\circ} \mathrm{C}$.

Colonies were purified by consecutive streaking onto the same medium.

The final liquid medium used for growth and maintenance of the strain was prepared as described by Pfennig et al. (19). This medium contained (per liter of distilled water) $3 \mathrm{~g}$ of $\mathrm{Na}_{2} \mathrm{SO}_{4}, 0.3 \mathrm{~g}$ of $\mathrm{KCl}, 0.3 \mathrm{~g}$ of $\mathrm{NH}_{4} \mathrm{Cl}, 1.2 \mathrm{~g}$ of $\mathrm{NaCl}, 0.4 \mathrm{~g}$ of $\mathrm{MgCl}_{2} \cdot 6 \mathrm{H}_{2} \mathrm{O}, 0.2 \mathrm{~g}$ of $\mathrm{KH}_{2} \mathrm{PO}_{4}, 0.1 \mathrm{~g}$ of $\mathrm{CaCl}_{2} \cdot 2 \mathrm{H}_{2} \mathrm{O}, 1$ $\mathrm{ml}$ of trace element solution SL12 (9), $10 \mathrm{mmol}$ of sodium lactate, $2.5 \mathrm{~g}$ of $\mathrm{NaHCO}_{3}, 4 \mathrm{ml}$ of a vitamin solution (19), 1.0 $\mathrm{g}$ of yeast extract, and $0.2 \mathrm{~g}$ of $\mathrm{Na}_{2} \mathrm{~S} \cdot 9 \mathrm{H}_{2} \mathrm{O}$; the $\mathrm{pH}$ was 7.4.

The purity of strains was checked by using both phasecontrast microscopy and growth tests in sulfate-free TYG medium (3) (tested both aerobically and anaerobically). Pure cultures were maintained as stock cultures in 120 -ml screwcap bottles containing liquid medium supplemented with 1 $\mathrm{ml}$ of a growth factor solution (19) per liter.

Morphology. Microscopic observations were performed and photomicrographs were obtained by using a Zeiss photomicroscope as described by Pfennig and Wagener (18). Flagella were observed with a Hitachi model 600 transmission electron microscope after negative staining with $1 \%$ phosphotungstic acid.

Physiological tests. We tested the utilization of energy sources, carbon sources, and electron acceptors in basal liquid medium by using the substrate concentrations shown 
TABLE 1. Electron donors and acceptors used by Desulfovibrio longus SEBR $2582^{\mathrm{Ta}}$

\begin{tabular}{|c|c|c|c|}
\hline \multirow{2}{*}{$\begin{array}{l}\text { Electron donor or } \\
\text { acceptor }\end{array}$} & \multicolumn{3}{|c|}{ Growth in the presence of: } \\
\hline & $\begin{array}{c}\text { Sulfate } \\
(30 \mathrm{mM})\end{array}$ & No sulfate & Lactate \\
\hline \multicolumn{4}{|l|}{ Electron donors } \\
\hline Lactate $(10 \mathrm{mM})$ & + & - & \\
\hline Pyruvate (10 mM) & + & - & \\
\hline Acetate $(10 \mathrm{mM})$ & - & & \\
\hline Formate $+\mathrm{CO}_{2}(10 \mathrm{mM})$ & + & & \\
\hline Formate + acetate $(10 \mathrm{mM})$ & + & & \\
\hline Ethanol $(10 \mathrm{mM})$ & - & - & \\
\hline Propanol $(10 \mathrm{mM})$ & - & & \\
\hline Fumarate $(10 \mathrm{mM})$ & - & & \\
\hline Malate $(10 \mathrm{mM})$ & - & - & \\
\hline $\mathrm{H}_{2}+\mathrm{CO}_{2}\left(10^{5} \mathrm{~Pa}\right)$ & - & - & \\
\hline $\mathrm{H}_{2}\left(10^{5} \mathrm{~Pa}\right)+$ acetate $(10 \mathrm{mM})$ & + & & \\
\hline \multicolumn{4}{|l|}{ Electron acceptors } \\
\hline Sulfate $(30 \mathrm{mM})$ & & & + \\
\hline Sulfite $(5 \mathrm{mM})$ & & & + \\
\hline Thiosulfate $(10 \mathrm{mM})$ & & & + \\
\hline Sulfur & & & + \\
\hline Nitrate $(10 \mathrm{mM})$ & & & - \\
\hline Fumarate (10 mM) & & & + \\
\hline
\end{tabular}

${ }^{a}$ The following substrates were tested and were not utilized by strain SEBR $2582^{\mathrm{T}}$ : succinate $(10 \mathrm{mM}), \alpha$-ketoglutarate $(5 \mathrm{mM})$, citrate $(5 \mathrm{mM})$, propionate $(10 \mathrm{mM})$, butyrate $(10 \mathrm{mM})$, isobutyrate $(5 \mathrm{mM})$, glucose $(5 \mathrm{mM})$, fructose (5 $\mathrm{mM})$, gluconate $(10 \mathrm{mM})$, methanol $(10 \mathrm{mM})$, isopropanol $(10 \mathrm{mM})$, butanol $(10 \mathrm{mM})$, glycerol $(10 \mathrm{mM})$, benzoate $(5 \mathrm{mM})$, gallate $(5 \mathrm{mM})$, catechol $(2$ $\mathrm{mM})$, nicotinate $(2 \mathrm{mM})$, lysine $(10 \mathrm{mM})$, methionine $(10 \mathrm{mM})$, cysteine $(5$ $\mathrm{mM})$, glutamate $(5 \mathrm{mM})$, aspartate $(5 \mathrm{mM})$, acetone $(5 \mathrm{mM})$, glycolate $(2 \mathrm{mM})$, thioglycolate $(2 \mathrm{mM})$, thioacetamide $(2 \mathrm{mM})$, peptone $(0.5 \mathrm{~g} /$ liter $)$, Casamino Acids $(0.5 \mathrm{~g} /$ liter $)$, and yeast extract $(0.5 \mathrm{~g} /$ /iter $)$. Glucose, fructose, succinate, and glycerol were not fermented. $n$-Alkanes from $C_{15}$ to $C_{40}$ were tested and were not utilized by strain SEBR $2582^{\mathrm{T}}$ after 1 month of incubation under anaerobic conditions.

in Table 1. Fermentative growth was tested in the same medium except that sulfate was omitted. These tests, as well as the tests used to determine the optimum concentrations of $\mathrm{NaCl}$ and $\mathrm{MgCl}_{2}$, the optimum $\mathrm{pH}$, and the optimum temperature, were performed in completely filled $25-\mathrm{ml}$ screwcap tubes with rubber seals. Growth was measured over a period of 15 days by determining optical density at $450 \mathrm{~nm}$ with a Bausch \& Lomb Spectronic 20 spectrophotometer. At the end of the experiments, sulfide production was checked in each screw-cap tube by using the method of CordRuwisch (5). The requirements for vitamins or growth factors were tested in $120-\mathrm{ml}$ anaerobic bottles after five consecutive transfers by using the experimental system of Goupy (11). Eight duplicated experiments were done for seven vitamins (biotin, $p$-aminobenzoate, thiamine, panthothenic acid, pyridoxine, cyanocobalamin, and nicotinic acid).

Pigments. The presence of bisulfite reductase (desulfoviridin) in strain SEBR $2582^{\mathrm{T}}$ was tested by using cell extracts and a Kontron Uvikon 860 spectrophotometer (24).

Disproportionation tests. The disproportionation of thiosulfate and sulfite was tested by using a basal synthetic medium that lacked sulfate and organic energy sources. The basal medium was supplemented with acetate (used as a carbon source by strain SEBR $2582^{\mathrm{T}}$ ) and either thiosulfate or sulfite as an energy source and electron acceptor (1). After incubation, disproportionation was tested by measuring the increases in optical density and sulfate and sulfide production (4a).

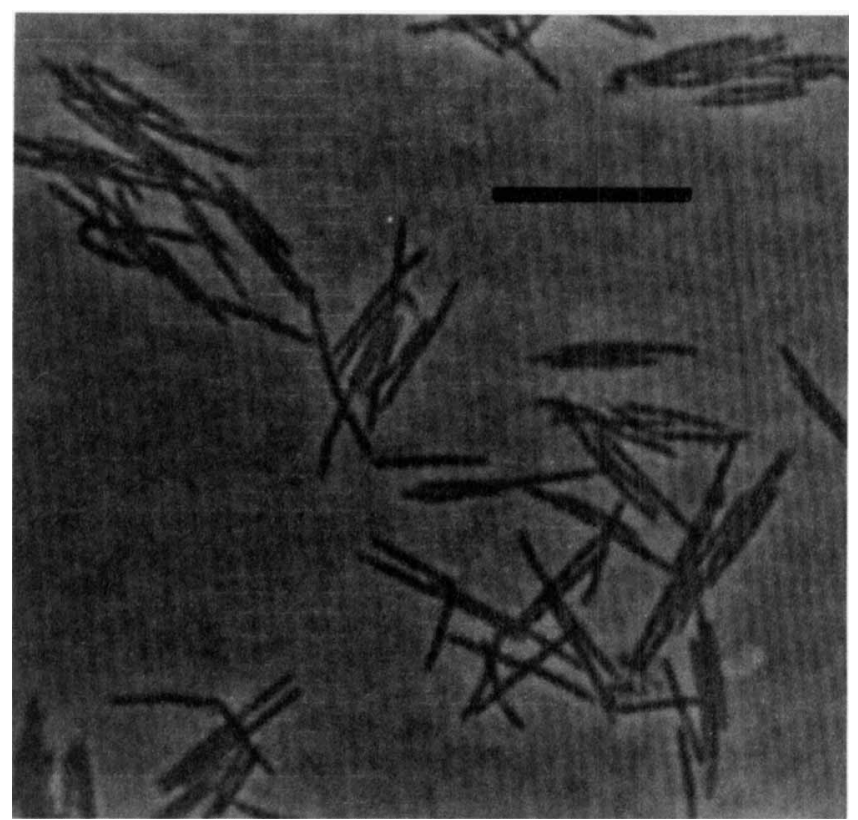

FIG. 1. Phase-contrast photomicrograph of Desulfovibrio longus SEBR $2582^{\mathrm{T}}$ grown with lactate as a carbon and energy source. Bar $=10 \mu \mathrm{m}$.

G $+C$ content of DNA and rRNA sequencing homology. The $\mathrm{G}+\mathrm{C}$ content of strain SEBR $2582^{\mathrm{T}}$ DNA was determined by the Identification Service of the Deutsche Sammlung von Mikroorganismen und Zellkulturen, Braunschweig, Germany. The DNA isolation and high-performance liquid chromatography procedures used have been described previously $(4,16)$.

rRNA extraction, primer-rRNA hybridization, the elongation reaction with reverse transcriptase, and electrophoresis of elongation products were performed as described previously (7). Of the 11 primers used, 8 were the same as those described by Embley et al. (10) (primers, 1, 2, and 4 through 9). Primer 11 (5'-ATTACTCACCCGTCCGCC-3') has been described by Dauga et al. (7). The following two primers were selected to ease sequencing of the $5^{\prime}$ end of the rRNA molecule: primer 10a (5'-CCCACCAACAAGCTAATGA-3') and primer $3 \mathrm{a}\left(5^{\prime}\right.$-TCTACGGATTTCACGCCTAC-3'). The sequence of $16 \mathrm{~S}$ rRNA from strain SEBR $2582^{\mathrm{T}}$ was compared with the 16S rRNA sequences of several species belonging to the genera Desulfovibrio, Desulfobulbus, Desulfotomaculum, Desulfococcus, Desulfobacter, and Desulfobacterium; the data were kindly provided by D. Stahl (8). The sequences that were compared were aligned manually. Positions where nucleotides could not be determined unambiguously were not included in the calculation. The divergence (or distance) between two sequences was estimated as the number of nucleotide substitutions $(\lambda)$. The $K_{\text {nuc }}$ values were determined as described by Hori and Osawa (12), using the following formula: $K_{\text {nuc }}=-3 / 4 \ln (1-$ $4 / \lambda)$. A phylogenetic tree was constructed by using the neighbor-joining method (22), as recommended by a committee of experts (17).

Nucleotide sequence accession number. The nucleotide sequence $(1,521$ nucleotides) of Desulfovibrio longus $16 \mathrm{~S}$ rRNA has been deposited with Genbank (EMBL) under accession number X63623. 


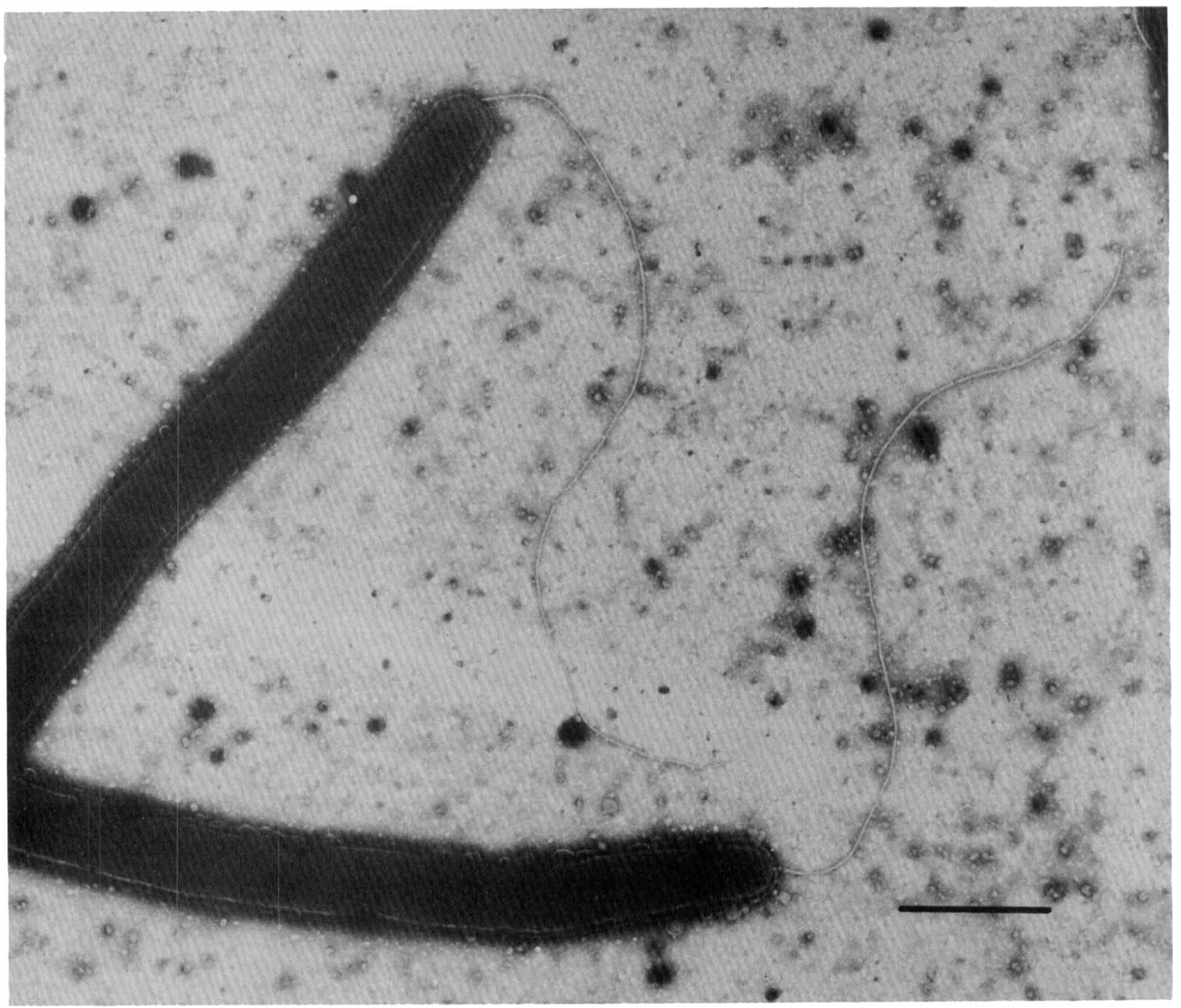

FIG. 2. Transmission electron micrograph after negative staining of Desulfovibrio longus $\mathrm{SEBR} 2582^{\mathrm{T}}$, showing the single polar flagellum. Bar $=1 \mu \mathrm{m}$.

\section{RESULTS}

Enrichment and isolation. From grey colonies that were 1 to $2 \mathrm{~mm}$ in diameter we obtained a pure culture after three consecutive transfers on solid media. The purity of this strain (strain SEBR $2582^{\mathrm{T}}$ ) was confirmed by the morphological homogeneity of cells observed under a phase-contrast microscope and by the absence of growth in liquid sulfatefree TYG medium under aerobic and anaerobic conditions.

Cell morphology. Individual cells of strain SEBR $2582^{\mathrm{T}}$ were long, thin, nonsporulating rods which were sometimes slightly curved (Fig. 1). Whole cells were 0.4 to $0.5 \mu \mathrm{m}$ wide and 5 to $10 \mu \mathrm{m}$ long under optimal conditions. The cells moved slowly by means of a single polar flagellum (Fig. 2). Gram staining was negative.

Pigment composition. The spectrum of cell extracts exhibited the characteristic absorption band of desulfoviridin at $631.5 \mathrm{~nm}$.

Physiological properties. The substrates that were tested as energy and carbon sources are shown in Table 1. Strain
SEBR $2582^{\mathrm{T}}$ used a rather limited number of substrates. Lactate, pyruvate, and formate were used as energy and carbon sources. $\mathrm{H}_{2}$ was also used as an energy source. Acetate was used only as a carbon source. $\mathrm{CO}_{2}$ was not used as a sole source of carbon by strain SEBR $2582^{\mathrm{T}}$.

None of the substrates which we tested was fermented.

Strain SEBR $2582^{\mathrm{T}}$ used sulfate, sulfite, thiosulfate, sulfur, and fumarate as electron acceptors in the presence of lactate as an electron donor and carbon source.

After five transfers strain SEBR $2582^{\mathrm{T}}$ did not grow without vitamins or yeast extract. Biotin, $p$-aminobenzoate, and thiamine significantly stimulated the growth of strain SEBR $2582^{\mathrm{T}}$. Associated biotin and $p$-aminobenzoate had a synergic effect.

In synthetic medium supplemented with lactate and sulfate, strain SEBR $2582^{\mathrm{T}}$ grew at $\mathrm{NaCl}$ concentrations between 0 and $8 \%$; optimum growth occurred $\mathrm{NaCl}$ concentrations of 1 to $2 \%$. The optimum $\mathrm{pH}$ was 7.4. Strain SEBR $2582^{\mathrm{T}}$ grew well between $\mathrm{pH} 6.5$ and 8.5 . The optimum 
UUCCCUGAGGGUUUGAUCCUGGCUCAGGGUGAACGCUAGCGGCGCGCCUAACCCAUGCAAGUCNAACGAGAAAGGGUCCUUCG GGACCUGAGUAGAGUGGCGCACGGGUGAGUAACGCGUAGGUGAUCUACCCUUAGGAUUGGGAUAACAGUUGGAAACGGCUGCU AAUACCGGAUACGCUCCAUAUUUAGCUUUUUGGUUGAAGGUGGCCUCUGCAUGCAAGCUACCACCUAAGGAUGAACCUGCGU CUCAUUAGCUUGUUGGUGGGGUNAUGGCUACNAAGGCGACGAUGAGUAGCUGAUCUGGGAGGAUGAUCAGCCACACUGGGAC UGGAACACGGCCCAGACUCCNNNNNNNNNNNNNNNNNNNNNNNNNNNNNNNNNNNNNNNNNNNNNNNACGCAGCGACGCCGCG UGAGGGAAGAAGGCUUCGGGUUCGUAAACCUCUGUCAGAAGGGAAGAAACCCUUGAGGGNGAAUAGGCCUCUUGGCUGACGGU ACCUUCAGAGGAAGCACCGGCUAAUUCCGUGCCAGCAGCCGCGGUAAUACGGAGGGUGCAAGCGUUAAUCGGAAUCACUGGGC GUAAAGCGCACGUAGGCGGUGCGGUCAGUCAGAUGUGAAACCUCGGCUCAACCGAGGAAUUGCAUUUGAUACUGCCGUGCUCG AGUACUGGAGAGGCAGGCGGAAUUCCANNGUUAGGAGUGAAAUCCGUAGAUAUCUGGAGGAACACCAGUGGCGAAGGCGGCCU GCUGGACAGAUACUGACGCUGAGGUNCGAAAGCGUGGGGAGCAAACAGGAUUAGAUACCCUGGUAGUCCACGCUGUAAACGAU GGAUGCUAGGUGUCGGGGGGUUCUUCGGUGCCGCAGUUAACGCGUUAAGCAUCCCGCCUGGGGAGUACGGUCGCAAGGCUGNN NNNNNNNNNNNNNNNNNNNNNNNNNNNNNNNNNNNNNNNNNNNNNNNNNNNNNNNNNNNNCGCGAAGAANCCUUACCUAGGC UUGACAUCCUNAGAACCCUCCCGAAAANGGAGGNNUGCCUUCGGGGNAUUCAGUGACAGGUGCUGCAUGGCUGUCGUCAGCUC GUGCCGUGAGGUGUUGGGUUAAUCCCGCAACGAGCGCAACCCUUGUUUCUUGUUGCCAGCGCGUAAUGGUGGGCACUCUAGU GAGACUGCCGGGGUUACCCGGAGGAAGGUGGGGACGACGUCAAGUCAUCAUGGCCCUUACGCCUAGGGCUACACACGUACUA CAAUGGCACGUACAAAGGGUUGCAAAGCCGCGAGGCAACGCCNAUCCCAAAAAACGUGUCCCAGUCCGGAUUGCAGUCUGCAA CUCGACUGCAUGAAGUUGGAAUCGCUAGUAAUCCCAGAUCAGAAUGCUGGGGUGAUACGUUCCCGGGCCUUGUACACACCGC CCGUCACAUACCACGUAAAGCUGGUUCUACCCGACAUCGGCAAGCUAACUUCGGGAGGCAGCCGCCUACGGUAGGACCGGUGA UUGGGGUGAAGUCGUAACAAGGUAGCC

FIG. 3. 16S rRNA sequence of Desulfovibrio longus SEBR $2582^{\mathrm{T}}$.

temperature was $35^{\circ} \mathrm{C}$. The strain was a normal mesophilic organism that grew at temperatures between 10 and $40^{\circ} \mathrm{C}$; it grew slowly at temperatures between 10 and $15^{\circ} \mathrm{C}$.

Under optimal conditions of salinity, temperature, and $\mathrm{pH}$ with lactate as an energy and carbon source, the mean doubling time of strain SEBR $2582^{\mathrm{T}}$ was about $3 \mathrm{~h}$ during exponential growth.

Sulfite was disproportionated, but thiosulfate was not.

The DNA base composition of strain SEBR $2582^{\mathrm{T}}$ was $62.3 \pm 0.6 \mathrm{~mol} \% \mathrm{G}+\mathrm{C}$ (as determined by high-performance liquid chromatography).

$16 S$ rRNA sequence. A total of 1,522 nucleotides of the $16 \mathrm{~S}$ rRNA sequence of strain SEBR $2582^{\mathrm{T}}$ were determined, corresponding to about $98 \%$ of the whole molecule (Fig. 3).

The phylogenetic tree obtained by using the neighborjoining method (22) is shown in Fig. 4.

Strain SEBR $2582^{\mathrm{T}}$ clustered with Desulfovibrio vulgaris, Desulfovibrio salexigens, and Desulfovibrio gigas. This cluster was distinct from the cluster that contained the genera Desulfobulbus, Desulfotomaculum, Desulfococcus, Desulfobacter, and Desulfobacterium, as previously shown by Devereux et al. (8).

\section{DISCUSSION}

Strain SEBR $2582^{\mathrm{T}}$, which was isolated from an oilproducing well in the Paris Basin, is strictly anaerobic and grows with lactate as an energy and carbon source and with sulfate as an electron acceptor, thus reducing sulfate. Strain SEBR $2582^{\mathrm{T}}$ is phylogenetically very closely related to members of the genus Desulfovibrio. On the basis of $16 \mathrm{~S}$ rRNA sequence data, strain SEBR $2582^{\mathrm{T}}$ clusters with Desulfovibrio vulgaris and Desulfovibrio salexigens. The $\mathrm{G}+\mathrm{C}$ content of the DNA of strain SEBR $2582^{\mathrm{T}}(62.3 \pm 0.6$ mol\%) is also similar to the DNA G + C contents of members of the genus Desulfovibrio (47.5 to $65 \mathrm{~mol} \%$ ).
Thus, despite its morphology (motile, long, gracile, rodshaped, nonsporulating cells), strain SEBR $2582^{\mathrm{T}}$ should be included in the genus Desulfovibrio (20).

Strain SEBR $2582^{\mathrm{T}}$ is the only Desulfovibrio strain with the morphology described above that is able to use formate but not fatty acids as both energy and carbon sources. Physiologically, strain SEBR $2582^{\mathrm{T}}$ resembles Desulfomicrobium apsheronum (21). Desulfomicrobium apsheronum cells are rod shaped and differ from strain SEBR $2582^{\mathrm{T}}$ cells by their size (small, short rods), their capacity for autotrophic growth, their fermentative metabolism, and their lack of desulfoviridin. Moreover, the G+C content of $D e$ sulfomicrobium apsheronum DNA (52 mol\%) is lower than that of strain SEBR $2582^{\mathrm{T}}$ DNA.

Among the species of the genus Desulfovibrio, Desulfovibrio baculatus is similar to strain SEBR $2582^{\mathrm{T}}$. Recently, Desulfovibrio baculatus has been transferred to the genus Desulfomicrobium as Desulfomicrobium baculatum (15). This short rod-shaped bacterium differs from strain SEBR $2582^{\mathrm{T}}$ physiologically and genetically; Desulfovibrio longus SEBR $2582^{\mathrm{T}}$ does not use malate but uses formate plus $\mathrm{CO}_{2}$, in contrast to Désulfomicrobium baculatum, which uses malate but does not use formate plus $\mathrm{CO}_{2}$. These organisms also differ in their DNA G+C contents $(57 \mathrm{~mol} \%$ for $\mathrm{De}$ sulfomicrobium baculatum and $62.3 \pm 0.6 \mathrm{~mol} \%$ for $\mathrm{De}$ sulfovibrio longus SEBR $2582^{\mathrm{T}}$ ).

A similar strain whose cells are long, gracile, and rod shaped was isolated and described by Jones (13). The energy and carbon sources used by this strain and strain SEBR $2582^{\mathrm{T}}$ are similar, as are the $\mathrm{G}+\mathrm{C}$ contents of their DNAs. However, the strain of Jones contains a special pigment in addition to desulfoviridin. Jones did not describe his organism as a new species of sulfate-reducing bacteria. Widdel (23) isolated and described a morphologically similar sulfate reducer and considered it to be a member of the genus 


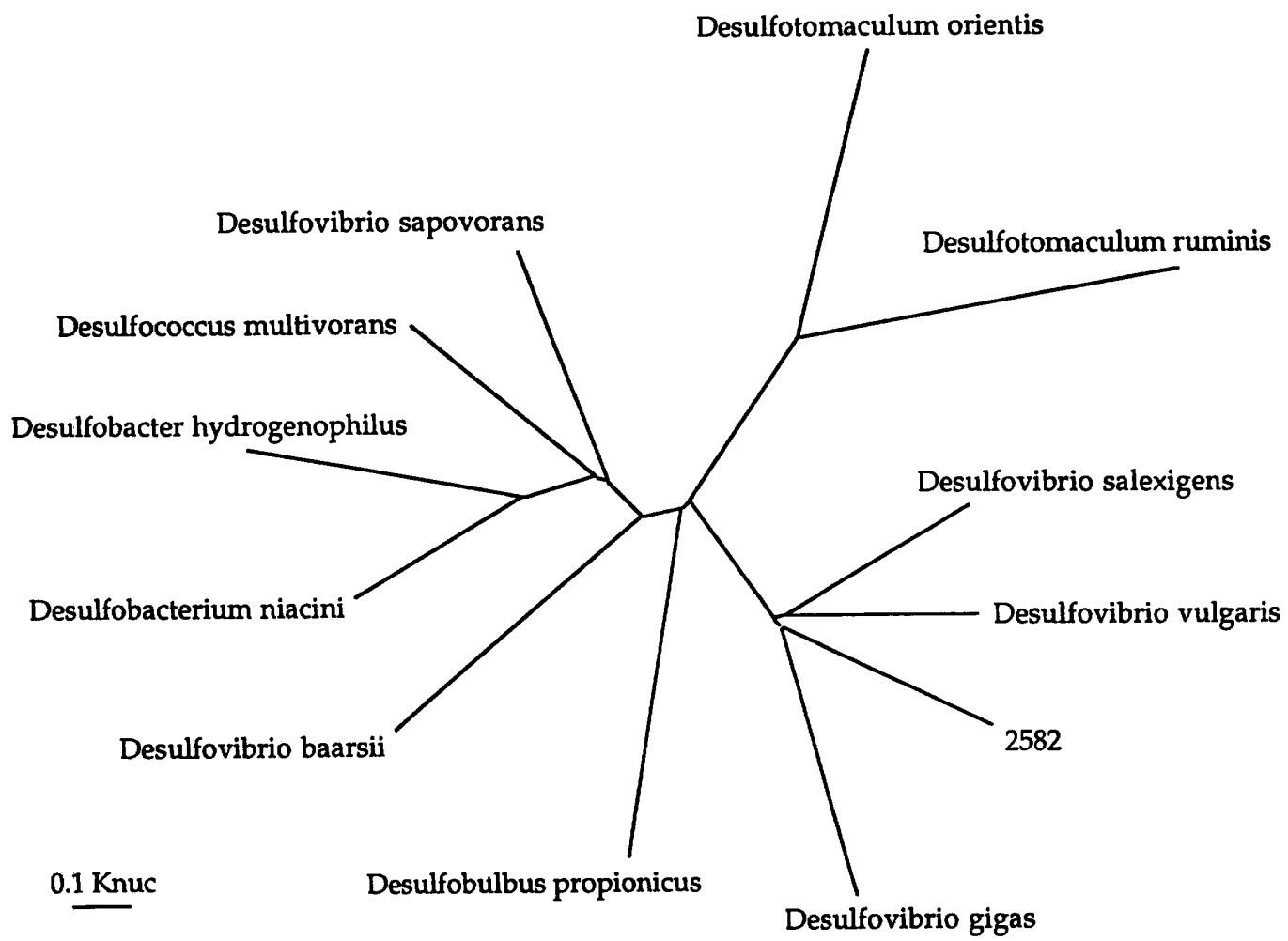

FIG. 4. Unrooted phylogenetic tree showing the relationships of Desulfovibrio longus SEBR $2582^{\mathrm{T}}$ and some other species of sulfate-reducing bacteria, based on a comparison of 1,522 nucleotides (16S rRNA).

Desulfovibrio. Unfortunately this strain was lost recently (23a).

Strain SEBR $2582^{\mathrm{T}}$ is a halotolerant organism which grows best in the presence of 1 to $2 \% \mathrm{NaCl}$ in synthetic medium, as Desulfovibrio salexigens and Desulfovibrio giganteus do (10a). However, it differs from these species morphologically as well as physiologically, particularly in its inability to utilize alcohols and malate. Thus, on the basis of morphological, physiological, and phylogenetic differences compared with other members of the genus, below we describe this strain as a new species of the genus Desulfovibrio, Desulfovibrio longus.

Description of Desulfovibrio longus sp. nov. Desulfovibrio longus (long'us. L. adj. longus, long). Long, thin, straight, rod-shaped cells that are 0.4 to $0.5 \mu \mathrm{m}$ wide and 5 to $10 \mu \mathrm{m}$ long. Gram negative. Motile by means of a single polar flagellum. The $\mathrm{pH}$ range is 6.5 to 8.5 ; optimum growth occurs at 7.4. The temperature range is 10 to $40^{\circ} \mathrm{C}$; optimum growth occurs at $35^{\circ} \mathrm{C}$. The salinity range is 0 to $8 \% \mathrm{NaCl}$; optimum growth occurs in the presence of 1 to $2 \% \mathrm{NaCl}$.

Strictly anaerobic. Reduces sulfate, sulfite, thiosulfate, and elemental sulfur with production of sulfide. Fumarate is reduced to succinate. Nitrate is not used as an electron acceptor. The substrates that are oxidized by anaerobic respiration of sulfur compounds or fumarate are $\mathrm{H}_{2}$, lactate, pyruvate, and formate. $\mathrm{H}_{2}$ is used only in the presence of acetate or yeast extract. Organic substrates are not fermented. Biotin and $p$-aminobenzoate are required as growth factors.

Desulfoviridin is present. The $\mathrm{G}+\mathrm{C}$ content of the DNA is $62.3 \mathrm{~mol} \%$ (as determined by high-performance liquid chromatography).
Habitat: production fluid from an oil-producing well in the Paris Basin.

The type strain is strain SEBR 2582, which has been deposited with the Deutsche Sammlung von Mikroorganismen und Zellkulturen as strain DSM 6739.

\section{ACKNOWLEDGMENTS}

We are grateful to R. Baulaigue for technical assistance, to J. C. Sigoillot for establishing the experimental system for vitamin tests, and to D. A. Stahl for providing rRNA sequences of reference strains. We also thank P. A. D. Grimont for helpful discussions and D. Shire for reading the manuscript.

\section{REFERENCES}

1. Bak, F., and N. Pfennig. 1987. Chemolithotrophic growth of Desulfovibrio sulfodismutans sp. nov. by disproportionation of inorganic sulfur compounds. Arch. Microbiol. 147:184-189.

2. Battersby, N. S., D. J. Stewart, and A. P. Sharma. 1985. Microbiological problems in the offshore oil and gas industries. J. Appl. Bacteriol. Symp. Suppl. 1985:225S-235S.

3. Brefort, G., M. Magot, H. Ionesco, and M. Sebald. 1977. Characterization and transferability of Clostridium perfringens plasmids. Plasmid 1:52-66.

4. Cashion, P., M. A. Holder-Franklin, J. McCully, and M. Franklin. 1977. A rapid method for the base ratio determination of bacterial DNA. Anal. Biochem. 81:461-466.

4a.Caumette, P., Y. Cohen, and R. Matheron. 1991. Isolation and characterization of Desulfovibrio halophilus sp. nov., a halophilic sulfate-reducing bacterium isolated from Solar Lake (Sinai). Syst. Appl. Microbiol. 14:33-38.

5. Cord-Ruwisch, R. 1985 . A quick method for the determination of dissolved and precipitated sulfides in cultures of sulfatereducing bacteria. J. Microbiol. Methods 4:33-36.

6. Cord-Ruwisch, R., W. Kleinitz, and F. Widdel. 1987. Sulfate- 
reducing bacteria and their activities in oil production. J. Petrol. Technol. 1987:97-106.

7. Dauga, C., F. Grimont, and P. A. D. Grimont. 1990. Nucleotide sequences of 16S rRNA from ten Serratia species. Res. Microbiol. 141:1139-1149.

8. Devereux, R., M. Delaney, F. Widdel, and D. A. Stahl. 1989. Natural relationships among sulfate-reducing eubacteria. J. Bacteriol. 171:6689-6695.

9. Eichler, B., and N. Pfennig. 1986. Characterization of a new platelet-forming purple bacterium, Amoebobacter pedioformis sp. nov. Arch. Microbiol. 146:295-300.

10. Embley, M., J. Smida, and E. Stackebrandt. 1988. Reverse transcriptase sequencing of $16 \mathrm{~S}$ rRNA from Faenia rectivingula, Pseudonocardia thermophila, and Saccharopolyspora hirsuta, three wall type IV Actinomycetes which lack mycolic acids. J. Gen. Microbiol. 134:961-966.

10a.Esnault, G., P. Caumette, and J. L. Garcia. 1988. Characterization of Desulfovibrio giganteus sp. nov., a sulfate reducing bacterium isolated from a brackish coastal lagoon. Syst. Appl. Microbiol. 10:147-151.

11. Goupy, J. 1988. La méthode des plans d'expérience. Dunod, Paris.

12. Hori, H., and A. S. Osawa. 1979. Evolutionary change in 5 S RNA secondary structure and phylogenetic tree of 54 5S RNA species. Proc. Natl. Acad. Sci. USA 76:381-385.

13. Jones, H. E. 1971. Sulfate-reducing bacterium with unusual morphology and pigment content. J. Bacteriol. 106:339-346.

14. Jorgensen, B. B. 1983. The microbial sulphur cycle, p. 91-124. In W. E. Krumbein (ed.), Microbial geochemistry. Blackwell Scientific Publications, Oxford.

15. Magot, M., L. Mondeil, J. Ausseur, and J. Seureau. 1988. Detection of sulphate-reducing bacteria, p. 37-52. In Biocorrosion. Proceedings of a Joint Meeting between the Biodeterioration Society and the French Microbial Corrosion Group. Biodeterioration Society, Kew, United Kingdom.

16. Meshbah, M., U. Premachandran, and W. Whitman. 1989.
Precise measurement of the $\mathrm{G}+\mathrm{C}$ content of deoxyribonucleic acid by high-performance liquid chromatography. Int. J. Syst. Bacteriol. 39:159-167.

17. Murray, R. G. E., D. J. Brenner, R. R. Colwell, P. De Vos, M. Goodfellow, P. A. D. Grimont, N. Pfennig, E. Stackebrandt, and G. A. Zavarzin. 1990. Report of the Ad Hoc Committee on Approaches to Taxonomy within the Proteobacteria. Int. J. Syst. Bacteriol. 40:213-215.

18. Pfennig, N., and S. Wagener. 1986. An improved method of preparing wet mounts for photomicrographs of microorganisms. J. Microbiol. Methods 4:303-306.

19. Pfennig, N., F. Widdel, and H. G. Trüper. 1981. The dissimilatory sulfate-reducing bacteria, p. 926-940. In M. P. Starr, H. Stolp, H. G. Trüper, A. Balows, and H. G. Schlegel (ed.), The prokaryotes, vol. 1 . Springer, Berlin.

20. Postgate, J. R. 1984. Genus Desulfovibrio, p. 666-672. In N. R. Krieg and J. G. Holt (ed.), Bergey's manual of systematic bacteriology, vol. 1. The Williams \& Wilkins Co., Baltimore.

21. Rozanova, E. P., T. N. Nazina, and A. S. Galushko. 1989. Isolation of a new genus of sulfate-reducing bacteria and description of a new species of this genus, Desulfomicrobium apsheronum gen. nov., sp. nov. Microbiology (Engl. Transl. Mikrobiologiya) 57:514-520.

22. Saitou, N., and M. Nei. 1987. The neighbour-joining method: a new method for reconstructing phylogenetic trees. Mol. Biol. Evol. 4:406-425.

23. Widdel, F. 1988. Microbiology and ecology of sulfate- and sulfur-reducing bacteria, p. 469-585. In A. J. B. Zehnder (ed.), Biology of anaerobic microorganisms. John Wiley \& Sons, Inc., New York.

23a.Widdel, F. Personal communication.

24. Widdel, F., and N. Pfennig. 1981. Studies on dissimilatory sulfate-reducing bacteria that decompose fatty acids. I. Isolation of new sulfate-reducing bacteria enriched with acetate from saline environments. Description of Desulfobacter postgatei gen. nov., sp. nov. Arch. Microbiol. 129:395-400. 